\title{
The Challenge of Productivity in the Housing Sector of a Developing Country: The Case of Cameroon
}

Minfede Koe Raoul1

1 Department of Public Economy, University of Douala, Cameroon.

To cite this article: Raoul, M.K. (2019). The Challenge of Productivity in the Housing Sector of a Developing Country: The Case of Cameroon. Journal of African Real Estate Research, 4(2), pp.24-41. DOI: 10.15641/jarer.v4i2.779.

\begin{abstract}
This paper evaluates productivity in terms of housing delivery levels of the housing sector in Cameroon. The data used is from the Centre for Affordable Housing Finance in Africa and the Ministry of Housing and Urban Development. These data relate to: the number of dwellings delivered during the study period; the amount of hours of work required to produce a housing unit; the unit cost of labour; the cost of producing a housing unit; and the area used to produce a housing unit. The technique of analysis was Data Envelopment Analysis. The level of productivity is evaluated using the Malmquist index. The results revealed that between 2010 and 2018 the housing sector in Cameroon produced an average of 13,126 houses per year. This production gives an average cost per housing unit of $\$ 39,612$. The study found a fall in total productivity of factors (labour and capital factors) to the order of $24.5 \%$ for the period considered. The fall observed is explained by a decrease in both technical efficiency and technological progress. To increase the productivity of the housing sector in Cameroon two types of measures are possible. Firstly, a better use of resources where particular attention is paid to the factors limiting productivity growth, namely the cost of labour, capital and materials. Secondly, use a skilled workforce and implement incentives for innovation based on the use of local materials and better operational organisation. It is argued that the incorporation of these suggestions would make it possible to increase the productive capacities of housing firms in Cameroon.
\end{abstract}

Keywords: Housing Sector; Productivity; Cameroon; Frontier Production; Malmquist Index 


\section{Introduction}

As early as 1776, Adam Smith opened the perspective of a vicious cycle of growth based on gains in productivity. From then the notion of productivity has received particular attention in economic analysis. The interest in the analysis of productivity comes from the competitiveness of firms, increase in incomes and the improvement in the well-being of populations (Englander \& Gurney, 1994). The theoretical basis of productivity is in efficiency (Leibenstein, 1966). From a conceptual viewpoint productivity translates the ratio between the volume of production to the volume of factors of production (Smith \& Stewart, 1963). As such, it enables the measurement of efficiency of the use of factors for a given level of production. In this vein, productivity is a measure of economic performance that enables the comparison between the quantity produced for a certain period with the inputs necessary to obtain this production (Dyckhoff \& Spengler, 2010). Productivity can be evaluated using two approaches; notably in physical units and in value 1 . In the latter case we obtain a number without unit that is useful only by comparison.

For several decades the growth of the productivity of the real estate sector has been one of the engines of growth in global productivity of developed countries. Maclennan and Miao (2015) established a linear correlation between the productivity of the housing sector and economic development in terms of job creation and the reduction of poverty. Hacker (2003), in his studies on the movements of previous years in socialist Poland revealed that a lower proportion of housing per inhabitant could have a negative effect on the productivity of labour. More recent studies by Krugman (2014) and Hsieh and Moretti (2014), revisited the question of productivity of the housing sector. They showed that high housing costs displaced households from areas where salaries and productivity are high and incite enterprises as well as qualified labour to migrate to areas where productivity is not maximal. In other words, the weak productive capacity of the housing sector reduced global productivity by introducing changes in the production capacity. According to Krugman (2014), these losses in productivity calls for housing programmes that are more sensitive to growth so as to increase the elasticity of the supply of housing. In this same vein, the capitalist development theory developed by Piketty (2014) attracts attention to the manner in which the housing market can lead to an economy of rents instead of harmonious economic development.

Several studies focusing on the sources of the growth in the productivity of the real estate sector were carried out based on the positive effects that the growth of productivity of the real estate sector can have on global growth (Stokes, 1981; Allen, 1985; Schriver \& Bowlby, 1985; Orr, 1989; Tan, 2000; Mason \& Osborne, 2007;). However, the studies mostly evaluate the growth of the productivity of labour. On the contrary, very few studies have evaluated productivity in terms of the stock of houses delivered by the real estate sector.

1 In the first case it is, for example, the number of houses per worker and per year, whereas in the second case, production and the factors are evaluated in monetary value. 
Moreover, this problem has not been studied much in Sub-Saharan African (SSA) countries such as Cameroon. This study's contribution is to begin to close this gap.

In Sub-Saharan Africa (SSA), the problem of the productivity of the housing sector is important because of the high demographic growth of SSA economies (2.7\% according to the World Bank, 2017). According to Centre for Strategic and International Studies (2018), SSA has experienced rapid urbanisation and a subsequent increase in populations living in slums. By 2050, SSA will have about 1.2 billion citizens and about five million informal houses. Further, currently more than half of the population in SSA do not have access to decent housing (World Bank, 2017). It is therefore clear that African countries South of the Sahara have to reinforce their productive capacity. This suggests the reduction of the obstacles to the optimal allocation of available resources (Duranton, 2008).

In Cameroon, according to the National Institute of Statistics (NIS, 2018a), the housing sector has registered a deficit of more than one million houses for two decades. The situation has a negative impact on the purchasing power of the population. The expenses on houses represent $33 \%$ of the income of poor households (NIS, 2018b). This is an important burden for the millions of poor families. This situation is not only unjust but also represents heavy losses in terms of well-being and individual productivity. A study carried out by the NIS (2010) on the performance of Cameroon firms revealed that between 1995 and 2010 the value added per head in the real estate sector had a stagnation of $1 \%$. For the same period, the total productivity of factors in terms of houses produced had years of growth alternating with years of decline between $1 \%$ and $2 \%$. In addition, the same study showed that the average rate of use of the production capacity of the real estate sector was evaluated at $31 \%$. This figure shows that there is an underuse of production resources in the real estate sector in Cameroon. Only $31 \%$ of the available resources are used. This rate is less than that obtained by other sector with rates of utilisation of production capacity of more than $60 \%$.

Recent statistics show that the contribution in terms of value added of the enterprises in the real estate sector to the national economy remains small $(0,168 \%)$. Moreover, between 2016 and 2018 the real estate sector had a growth rate of $2.1 \%$. On the contrary the dynamics of inflation in 2017 resulted in a $1.2 \%$ increase in the prices of goods of the real estate sector (INS, 2018a). According to the World Bank (2018), the housing sector of Cameroon, just like in most countries of SSA, have production costs of 30$40 \%$ higher than those of other areas of the world.

All these raise questions on the productive capacity of the real estate sector to meet up with the long-term economic and social expectations. It is in this perspective that this study aims to evaluate the growth of the productivity in terms of the volume of houses delivered in the real estate sector of Cameroon.

This study is of interest for at least two reasons. First, it has the particularity of treating the issue of the productivity of the real estate sector under the prism 
of the volume of housing delivered. In addition, contrary to previous studies, this study has the particularity of using a model that is nevertheless popular in other studies but which is not very often used in the real estate sector. Second, it is one of the first studies on productivity in the SSA context, and particularly in Cameroon. The evaluation of the productivity of the housing sector in Cameroon has implications for economic efficiency and the improvement of the quality of life of the Cameroonian population. The results of this study can be used as a policy tool in decision making.

The paper is structured into five sections. The first section discusses the problem and presents the paper's aim. The second section provides the review of literature. The third section deals with the methodology. The fourth section presents the results and discussions. While fifth section gives the conclusion of the study and the economic policy implications.

\section{Literature Review}

Two points are articulated in this section. The first point precises the theoretical framework of productivity models. The second point shows the state of empirical literature. Analysis of productivity in economics is not new. The articulation retained in this section allows us, on the one hand, to better grasp the theoretical controversies in order to identify the coherent framework of our analysis, and on the other hand, it allows us- from an empirical point of view- to identify the knowledge gap that justifies our study.

\subsection{The Theoretical Framework of the Productivity Models}

The theoretical anlysis of productivity has been intensively debated throughout the history of economic thought. Although Adam Smith is considered to be the spearhead of a transformation in the understanding of productivity, the preoccupation is already present among philosophers of natural law and French physiocrats who located productivity in a surplus of natural goods (Quesnay, 1766). The contribution of Smith (1776) is striking in that it opens up the prospect of a virtuous cycle of growth based on productivity gains. For Smith, productivity gains result from the division of labour. The author advocated the organisation of tasks as an explanatory factor for productivity gains. This vision is not agreed by other classical authors like David Ricardo and Karl Marx. For them, productivity gains are the result of variations in capital intensity of productive processes on labour through machinery (Jessua, 1991). However, classical thoughts share a rather pessimistic view: long-term productivity gains are destined to disappear gradually to cancel each other out in a "stationary state". The reason for this lies in the evolution of the distribution of national income, induced by the accumulation of factors: labour, capital and land.

Such a conclusion is questioned by the proponents of the neoclassical school. Solow (1956) provided an answer to the pessimistic predictions of classical authors. This author built a growth model generating more and more activity over time. Solow raised the hypothesis of rigidity of the production technique as postulated by the classics, enabling him to fracture the sources 
of growth. It showed that sustainable productivity gains can be explained by shifting production techniques. However, Solow viewed technical progress as exogenous to the model. According to the theorists of endogenous growth, productivity is explained by the behavior of economic agents accumulating physical capital (Romer, 1986), technology (Lucas, 1988), human capital and public capital (Barro, 1990). In this case the technical progress is not exogenous but rather endogenous to the model.

The evolutionary theory contributed to this reflection by amending previous conclusions (Penrose 1959; Leibenstein 1966; Nelson \& Winter, 1982). Indeed, it is part of a neo-Schumpeterian perspective insisting on an economic analysis of technological and organisational dynamics. It considers productivity as the result of an accumulation of competences. These competences are built over time through the effects of learning and routines. Learning is a cumulative process involving organisational and collective competences, spurring new opportunities in the production process (Libenstein, 1966). According to Nelson and Winter (1982), routines improve human capital, encourage organisational and technological innovation; therefore, a source of technological change and growth productivity (Nelson \& Winter, 1982).

The theories discussed above have represented a certain advancement towards productivity modeling for the purpose of researching the actual sources of productivity growth in economies. Under the assumption of overall economic growth driven by sectoral productivity gains, several studies have been conducted in different sectors of modern and developing economies. The construction sector is not isolated from these reflections.

In order to measure the growth of the productivity of the housing sector the previous studies use different techniques namely: the technique of price indices; the econometric technique of estimation of national production functions, and the linear programming technique. The technique of price indices was used in several sectors including the housing sector (Stokes, 1981; Allen, 1985; Schriver \& Bowlby, 1985). It considers a set of vectors of products and factors of production associated to a price vector. Three indices are generally used, in particularly the index of Paasche $(\mathrm{P})$, the index of Laspeyers (L) and the index of Fisher (F) (see Diewert, 2002 for a discussion of the choice of the best index). The calculation of the indices is based on the principle of weighting by the quantities or the prices when it involves the price and quantity indices respectively. This technique considers that the factors of production have different degrees of importance. For example, the weighting by prices consists of placing the most costly goods with the least costly ones. This technique has the particularity of aggregating good production units To several researchers, the calculation of productivity using the method of indices has limits related to the use of current price deflators which can either underestimate or overestimate production (Cassimatis, 1969; Pieper, 1991). In addition, the calculation of indices is not based on any economic hypothesis especially that related to production technology (Farrell, 1957). It is however adapted to the analysis of productivity at the national level. 
Other studies use the technique of compatibility of growth (Dacy, 1965; Schriver \& Bowlby, 1985; Orr, 1989; Chau, 1993; Mason \& Osborne, 2007). This technique is based on the definition of an aggregate production function that translates the manner in which an economy uses factors of production in an optimum manner for production (Solow, 1957). The objective of this method is to evaluate the determinants of the growth of productivity. Several forms of the production function are generally used: the Cobb-Douglas function; the function of Constant Elasticity of Scale (CES) and the function of Variable Elasticity of Scale (VES). In order to appreciate the growth of productivity, one supposes the existence of a neoclassic function such that: $F(A, K, L)$. It defines a production technology that represents the manner in which factors of production are combined, namely capital $(K)$ and labour $(L)$. The factor $A$ translates a level of technology enabled to appreciate the total productivity of factors. However, the measure of the growth of productivity will depend on the hypotheses made on the national economy (increasing returns, decreasing returns etc.). This approach is often criticised for several reasons:

i) The difficulty of establishing an aggregate production function.

ii) The results obtained depend on the form of the production function chosen.

iii) Given the different products and services rendered by the housing sector which vary with time, it is very difficult to define an exact unique form of a long-term production function (Carlaw \& Lipsey, 2001).

iv) This technique does not take into account the efficiency of firms which is an essential notion for the measurement of the growth of productivity of firms. In other words, no distinction is precised between pure technological changes and changes in efficiency or an optimal allocation of resources.

In order to overcome these limitations, other researchers define an additional theoretical framework for the analysis of productivity adapted to several sectors including the housing sector. The theoretical framework proposed is that of the distance function, as initiated by Shephard (1953). The distance functions are defined for a particular production technology. The technique used is that of Data Envelopment Analysis (DEA) (Farrell, 1957). It tries to analyse the manner in which a firm, with a given level of technology, combines different factors of production to obtain a product in an economically efficient manner. It supposes the existence of an optimal production frontier that represents best practice. With the aim of positioning itself on the optimal production frontier (efficient behaviour) the firm can have two types of behaviour: it can either maximise production or minimise the factors of production (Koopmans, 1951). In theory, the analysis of productivity from the distance function tries to examine the evolution (the growth or otherwise) of the efficiency of the firm over time. It involves the measurement of the extent to which the behaviour of a firm is far away from a situation of optimal production on the basis of a production technology. 
Even though this method is largely used and recognised as pertinent for the evaluation of productivity in several sectors, it however remains less exploited in the housing sector. This method has the advantage that it is based on a theoretical framework of the rational management of resources. In other words it permits to distinguish the gains from efficiency from those from pure technical progress. The theoretical framework exposed has been used by several studies which conclusions revealed varied results.

\subsection{Empirical Review}

Stokes (1981), Allen (1985) and Schriver and Bowlby (1985) used the approach of price indices in the context of the United States. They found a fall in the productivity of the housing sector without determining the cause. The studies of Allen (1985) showed that from 1968 to 1978, the movement from a highly productive industry to a lowly productive one reduced productivity in housing by $0.46 \%$ per year. Tan (2000) used the same technique in Singapore and obtained the same results between 1980 and 1996.

Kazaz, Manisali and Ulubeyli (2010) defined an Index of Relative Importance (IRI). On a sample from 0 to 5, they evaluated the productivity of labour of the housing sector in Turkey. They showed that the growth of the productivity of labour is attributed to organisational factors. In the same vein in Uganda, Alinaitwe, Mwakali and Hansson (2007) established an average index of the importance of productivity. They evaluated the productivity of labour of the Ugandan housing sector. They found a fall in the productivity of labour of the housing sector. In addition, they indicated that a fall in the productivity of labour in the housing sector is due to lack of competence and technology.

By defining the respective production functions that represent the sector other studies are realised. Dacy (1965) was the first to estimate a production function in the construction industry of the United States. The results he obtained revealed the growth of productivity between 1947 and 1963. Later studies were carried out in the United States (Borcherding, 1976; Koch \& Moavenzadeh, 1979; Maloney, 1983; Schriver \& Bowlby, 1985; Koehn \& Caplan, 1987); Hong Kong (Chau, 1993 ); and in the Nertherlands (Orr, 1989; Mason \& Osborne, 2007). All these studies revealed a growth of the productivity of labour in the construction industry. Law (1987) evaluated the total productivity of factors in the construction sector of the United Kingdom. He used the cost per unit of production in the construction sector as the output. With the help of a production function of the sector they found a growth in the total productivity of the factors. In addition, they show that the growth of the productivity of capital is less than that of the productivity of labour.

In the same vein, and more specifically to the real estate sector, other studies are carried out. They generally used the approach of the functions of production representing the real estate sector. Chen, Jefferson and Zhang (2011) studied the growth of the productivity of labour of the real estate sector between China and the United States with the help of the production function and they showed that the Chinese real estate sector had a delay in the productivity of labour with respect to that of the United States. They revealed 
that this delay was due to the lack of efficiency of Chinese equipments. Corrado, Haskel and Jona-Lasinio (2017) examined the channels through which used assets' effect on the productivity of the real estate sector. From a national production function they found a positive effect of immaterial capital on the productivity of the real estate sector. They showed that this effect transits through the new technologies of information and communication. Oloke et al. (2017) used a regression on panel data to evaluate the growth of productivity of employees in the real estate sector of Nigeria. They established a positive correlation between salary incentives and the growth of the productivity of employees in the Nigerian real estate sector.

The literature above suggests two major conclusions. The first is that there is a lack of consensus on the techniques used to measure the growth of productivity of the real estate sector. This divergence in tools translates the plurality of the objectives of each study. This shows that the debate on the productivity of the real estate sector remains current. The second is that housing productivity in SSA is less examined. This study tries to improve what is known about this topic in Cameroon. The methodology adopted as well as the results obtained are presented in the next sections.

\section{Methodology}

The idea of the methodological approach of this study is to relate the factors of production and the level of production of the housing sector in Cameroon. We want to establish the contribution of each factor of production to the total production of the housing sector. This allows us to see how companies in the housing sector use the factors of production. The use of the productivity model will reveal whether companies in the housing sector make rational use of available resources (capital, labor, technology, etc.). We reason from a normative production function reflecting the best use of resources. The ultimate goal of this reasoning is to see if the housing sector is capable of achieving growth gains that tend towards the best use of resources. In this section we first specify the model used; then we define the variables and finally we present the data used.

\subsection{Specification of the Model}

This study measures the growth of productivity in terms of the volume of houses delivered between 2010 and 2018 in Cameroon. The housing sector in Cameroon is particularly heterogeneous in nature (comprising of a minority of large formal enterprises and a majority of small enterprises, sometimes informal), making it difficult to associate a precise production function. Moreover, the rational management of resources is one of the major problems faced by enterprises in Cameroon's housing sector. In addition, these enterprises are generally exposed to exogenous fluctuations in prices of imported factors of production thus reducing their margin of liberty in terms of planification. For all these reasons the method of DEA seems to be better adapted for this study. We use the index of decomposition of productivity proposed by Malmquist (1953). This index involves the comparison of the observed production between two periods for different baskets of factors of 
production. This approach takes into account the technology available for each period.

The index of Malmquist permits researchers to distinguish the movements of the production frontier, that is: technological changes (techch), and the movement of firms towards the frontier that is change in efficiency (effch). Under the hypothesis of variable returns to scale (VRS), change in efficiency (effch) is decomposed into change in pure efficiency (pech) and change in efficiency of scale (sech). The change in pure efficiency measures the evolution of the proximity of firms to the frontier without scale effect. Whereas the change in efficiency of scale indicates if the movements in the frontier are in the right direction. This is to attain the reference point where the modifications of production leads to modifications proportional to costs. It is therefore possible to obtain an index of total productivity of factor by making the product of the index of change in technological efficiency, the index of change in pure efficiency and the index of change in efficiency of scale. Any value higher than one indicates growth; any value less than one translates a decline/fall. Whereas any value equal to one indicates the stagnation of each index.

The formulation of the Malmquist index is based on the definition of a production technology as established by Fare et al. (1994). According to these authors, for each period $t=1,2, \ldots, T$, there exist a technology given by:

$$
P(x)=\left\{x \in R_{+}^{N}: x \text { can produce } y ; y \in R_{+}^{M}\right\}
$$

Following this technology the calculation of the index of Malmquist implies the definition of two distance functions (Farrell, 1957). The first distance function orientated output is defined as follows:

$$
D_{0}^{t}(x, y)=\min \left\{\lambda:\left(x_{i}^{t}, \frac{y_{i}^{t}}{\lambda}\right) \in P(x)\right\}=\left[\max \left\{\lambda:\left(x_{i}^{t}, \lambda y_{i}^{t}\right) \in L(y)\right\}\right]^{-1}
$$

The expresion of the curve translates the technology of units of production of the housing sector. The second distance function that enables the calculation of the index is given by the expression:

$$
D_{0}^{t}\left(x_{i}^{t+1}, y_{i}^{t+1}\right)=\min \left\{\lambda:\left(x_{i}^{t}, \frac{y_{i}^{t}}{\lambda}\right) \in P(x)\right\}
$$

This expression measures the maximum proportional change of output obtained at period $t+1$, relative to the technology used at period $t$. If we assume that a unit of production in the housing sector uses a quantity $x$ of input in view of obtaining the quantity $y$ of output, the index of Malmquist enables to measure the evolution of the productivity between two periods. We formalise this index in the following manner:

$$
M_{t}^{t+1}=\left[\frac{D_{0}^{t}\left(x^{t+1}, y^{t+1}\right)}{D_{0}^{t}\left(x^{t}, y^{t}\right)}\right]^{1 / 2}\left[\frac{D_{0}^{t+1}\left(x^{t+1}, y^{t+1}\right)}{D_{0}^{t+1}\left(x^{t}, y^{t}\right)}\right]^{1 / 2}
$$




$$
M_{t}^{t+1}=\left[\frac{D_{0}^{t}\left(x^{t+1}, y^{t+1}\right) D_{0}^{t+1}\left(x^{t+1}, y^{t+1}\right)}{D_{0}^{t}\left(x^{t}, y^{t}\right) D_{0}^{t+1}\left(x^{t}, y^{t}\right)}\right]^{1 / 2}
$$

In equation (4), the first expression measures the displacement of a firm in the housing sector between two periods $(t$ and $t+1)$ relative to the efficient frontier of period $t$. The second expression of equation 4 measures the displacement of the same firm with respect to the efficient frontier of the period $t+1$. The calculation of the index of Malmquist is thus carried out as the geometric mean of these two terms (Coelli et al., 1998). For a more refined interpretation of the index of Malmquist, Fare et al. (1994) proposed a decomposition based on a product with two terms. They later express the main sources of growth in productivity. The product of the two terms is defined as follows:

$$
M_{t}^{t+1}=\frac{D^{t}\left(y^{t}, x^{t}\right)}{D^{t+1}\left(y^{t+1}, x^{t+1}\right)} \cdot\left[\frac{D^{t+1}\left(y^{t+1}, x^{t+1}\right)}{D^{t}\left(y^{t+1}, x^{t+1}\right)} \cdot \frac{D^{t+1}\left(y^{t}, x^{t}\right)}{D^{t}\left(y^{t}, x^{t}\right)}\right]^{1 / 2}
$$

The first expression represents the change in efficiency of each firm in the housing sector between the period's $t$ and $t+1$, with respect to the pertinent frontiers of each period. The second expression translates the progress in technology between the two periods.

The appreciation of the results is done according to the following decision criterion: we must always keep in mind that productivity reflects the efficiency of a firm over time. Efficiency is approached from an optimal production boundary. Since the coefficient of efficiency is between zero and one (Farrell, 1957), any value less than one exhibits a dynamic fall in productivity, because the firm is below the optimal boundary. The rate of the decrease is obtained by making a difference between the optimal value (that is one ) and the result obtained after calculation. Also, it is applied as well for any value greater than 1 , which would translate a growth of productivity. The productivity growth rate is also obtained by making a difference between the optimal value (i.e. one) and the value derived from the calculation. And finally, any value equal to one would translate into a stagnation of productivity. Stagnation reflects the idea of productivity stability (no decline and no growth) over time.

\subsection{Variables of the Study}

From an operational stand point, the production of housing requires: the availability of viable land, the mobilisation of construction material, the availability of long-term financing, the presence of qualified man power, and the utilisation of technologies.

\subsubsection{Choice of Inputs}

From a theoretical point of view two factors are usually used: labour and capital (Law, 1987; Mason \& Osborne, 2007; Chen et al., 2011). This study equally retains these two factors. 


\section{- The Labour Factor}

The evaluation of the productivity of labour raises the debate on the choice of the indicator. Literature proposes the number of employees, expenses on the salaries of the employees, and the number of hours of labour. Each of these indicators has advantages and disadvantages (Stokes, 1981; Maloney, 1983; Oloke et al., 2017; Hsieh \& Moretti, 2019). A simple identification of salaried employees would mask the variations in the average number of hours of work in enterprises provoked by the evolution of part time labour, variations in overtime hours, and the absence of the place of work or modifications of the normal working period. The expenses on the salaries of employees are of particular interest from an economic stand point, but in the case of the production of houses it is often difficult to estimate the cost of labour. Very few enterprises in the housing sector have permanent workers and labour is often recruited informally. For this purpose, it is difficult to establish a salary database. For all these reasons we retain as the indicator of the factor labour: «the real number of hours of labour».

\section{- The Capital Factor}

In the housing sector capital has a technical character. It refers to all the producer goods, including: machines, industrial installations, communication or transport networks, raw materials, energy, etc. From these different components literature retains two types of capital: fixed and circulating (Smith, 1776). The first type refers to all the installations which do not disappear in the production process. Fixed capital items are generally used for production for many years; they undergo each year a certain wear and end up being unusable. This is the material wear of machinery and equipment. The second type refers to all intermediary consumptions engaged in the production process. This is the part of the capital expended for the purchase of the labour force, as well as for the purchase of means of production: raw materials, fuel and other auxiliary materials, which do not enter into the composition of fixed capital.

The production of houses requires fixed capital in the form of land. No production of houses is possible without land. In Cameroon, the problem of land tenure is very crucial. In this context the rational management of land becomes a source of efficiency in the housing sector (CAHF, 2017). The availability of land is a constraint for most firms in the housing sector in Cameroon. In order to take this constraint into account we retain the following as indicators of fixed capital: «the surface area used to produce a unit of standard house».

Moreover, the mobilisation of financial resources is an essential element in the production of houses. In most SSA countries the financing of the housing sector is still at its infancy. In Cameroon, the system of mortgage loans is not well developed (World Bank, 2017). Consequently, very few banks are engaged in the financing of real estate investments. The housing sector in Cameroon is mostly supported by small firms. Most of these firms cannot meet the loan conditions of formal banking finance. In these situations these firms resort mostly to informal financing and to formal micro credits. It is 
therefore difficult to clearly evaluate the volume of financing received by firms in the sector. For all these reasons we retain the following as financial capital: «the estimated cost of production of a unit of house». The estimated cost integrates the cost of infrastructure, the cost of construction material, the labour cost and the development cost.

\subsubsection{Choice of Output}

In the literature there is no consensus on the choice of output (Gullickson \& Harper, 1999). We evaluate the production capacity of the housing sector. which involves examining if each factor used enables the improvement of the level of production in the housing sector. This level is measured by the number of houses produced. That is why we retain as output: «the number of houses produced per year and per sector».

\subsection{Data}

The questions contained in the questionnaire were all closed-end type structured as inspired by other related studies.

The data used is from the Center for Affordable Housing Finance in Africa (CAHF, 2018) and from the Ministry of Housing and Urban Development (MINHDU, 2018). The CAHF is a non-profit organisation with the aim of reinforcing the capacity of public and private agents with the aim of creating a financing system that is capable of ensuring access to housing for all. Since 2010, it has collected information relative to the housing market of different African countries with the participation of different states and local African actors. The information collected relates to the indicators of economic growth, the system of financing houses, the costs of production, the prices of houses, and regulatory policies. In the case of this study we will exploit only the information on the costs of production per unit of housing as well as the surface area of land used per unit of housing produced. MINHDU is a government institution in charge of housing in Cameroon. Each year they produce databases on the performance of the real estate sector in Cameroon. This database presents information on: the size of the real estate sector; the volume of housing produced each year by the sector; the number of hours of labour per employee; the cost of factors of production, and many others. The study is based on 123 units of production of the real estate sector in Cameroon. These production units are authorised to exercise on the entire national territory in conformity with law no. 97/003 on real estate activities in Cameroon. The data used is for the peroid from 2010 to 2018.

The use of all the above information enabled the researchers to obtain a series of results that are presented below.

\section{Results}

\subsection{Descriptive Results}

The statistics of the different variables retained are in the table below. 
Table 1: Descriptive Statistics of Input and Outputs Retained

\begin{tabular}{|l|c|c|c|c|c|}
\hline & $\begin{array}{c}\text { Number of years } \\
\text { of observation }\end{array}$ & Minimum & Maximum & Mean & $\begin{array}{l}\text { Standard } \\
\text { deviation }\end{array}$ \\
\hline $\begin{array}{l}\text { The estimated cost of } \\
\text { production of a unit } \\
\text { of house }\end{array}$ & 9 & $18,500.00$ & $56,000.00$ & $39,612.11$ & $15,092.85$ \\
\hline Cost of labour & 9 & $3,900.00$ & $11,805.00$ & $8,350.22$ & $3,181.57$ \\
\hline $\begin{array}{l}\text { Number of hour of } \\
\text { labour }\end{array}$ & 9 & 40.00 & 60.00 & 50.44 & 6.85 \\
\hline $\begin{array}{l}\text { Surface area of land } \\
\text { used }\end{array}$ & 9 & 50.00 & 250.00 & 166.77 & 74.97 \\
\hline $\begin{array}{l}\text { Number of houses } \\
\text { produced every year }\end{array}$ & 9 & $12,000.00$ & $14,220.00$ & $13,126.66$ & 798.12 \\
\hline
\end{tabular}

Source: Author from data of CAHF and MINHDU (2018)

From 2010 to 2018 the housing sector in Cameroon has produced an average of 13,126 houses (see Table 1). This production gives an average cost per unit of house of $\$ 39,612$. It incorporates about 50 hours of work every day and requires an average consumption of $167 \mathrm{~m} 2$ of land. These statistics reveal a less productive sector since the demand for houses in Cameroon is estimated at more than one million houses. The annual growth in demand is evaluated at 10\% (NIS, 2018). However it is noticed that the housing sector in Cameroon is capital and labour intensive. This can lead to a relatively weak productivity of factors. To clarify this first tendency, we analyse the results of the productivity model. This is presented below.

\subsection{Results of the Productivity Model}

The Table 2 below gives the decomposition of the index of Malmquist into its sub-components.

Table 2: Total Productivity of Factors of the Housing Sector between 2010 and 2018

\begin{tabular}{|l|c|c|c|c|c|}
\hline Years & $\begin{array}{c}\text { Change in } \\
\text { Technical } \\
\text { Efficiency }\end{array}$ & $\begin{array}{c}\text { Change in } \\
\text { Technological } \\
\text { Efficiency }\end{array}$ & $\begin{array}{c}\text { Change in Pure } \\
\text { Efficiency }\end{array}$ & $\begin{array}{c}\text { Change in Efficiency } \\
\text { of Scale }\end{array}$ & $\begin{array}{c}\text { The Total } \\
\text { Productivity of } \\
\text { Factors }\end{array}$ \\
\hline 2010 & 0.967 & 0.666 & 0.915 & 1.057 & 0.644 \\
\hline 2011 & 0.353 & 0.875 & 0.526 & 0.672 & 0.308 \\
\hline 2012 & 0.363 & 1.010 & 0.535 & 0.680 & 0.366 \\
\hline 2013 & 0.406 & 0.876 & 0.580 & 0.701 & 0.355 \\
\hline 2014 & 0.441 & 0.810 & 0.605 & 0.730 & 0.357 \\
\hline 2015 & 0.968 & 1.138 & 0.906 & 1.069 & 1.101 \\
\hline 2016 & 1.751 & 0.907 & 0.970 & 1.806 & 1.588 \\
\hline 2017 & 1.052 & 0.876 & 1.027 & 1.025 & 0.921 \\
\hline 2018 & 1.801 & 0.645 & 1.121 & 1.607 & 1.161 \\
\hline Mean & $\mathbf{0 . 9 0 0}$ & $\mathbf{0 . 8 6 7}$ & $\mathbf{0 . 7 9 8}$ & $\mathbf{1 . 0 3 8}$ & $\mathbf{0 . 7 5 5}$ \\
\hline $2010-2011$ & 0.666 & 0.770 & 0.720 & 0.864 & 0.476 \\
\hline $2012-2018$ & 0.968 & 0.894 & 0.820 & 1.088 & 1.001 \\
\hline $2010-2018$ & 0.900 & 0.867 & 0.798 & 1.038 & 0.755 \\
\hline
\end{tabular}

Source: Author from data of CAHF (2011-2018) and MINHDU (2018) 


\subsubsection{Interpretation of the Results}

The Interpretation of the results obtained follows a very simple logic: the researchers consider that the firms of the housing sector in Cameroon evolve in an input/output space. From this space we can identify the best performing firms. That is those which are on the efficient frontier. Then we compare the existing firms to this frontier. This production frontier represents all the efficient observations for which no other production unit uses more or less input without modifying the quantity produced nor produces more or less of each product without modifying the quantity of input. However, from a dynamic perspective the production frontier can witness changes related to the reinforcement of human capital and externalities of technology. For this reason, we will finally analyse the movements of the frontier, the movements of the firms towards the frontier, the change in pure efficiency, the change in efficiency of scale as well as the variation in the total productivity of factors.

We observe that the housing sector has recorded between 2010 and 2018: an average fall in total productivity of $24.5 \%$, a regression in technical efficiency of $10 \%$, a fall in technological progress of $13.3 \%$, and a deterioration in pure efficiency of $20 \%$. However, the fall in productivity is compensated by an increase in efficiency of scale $(3.8 \%)$. These results indicate that the fall in the productivity of the housing sector in Cameroon is as a result of pure efficiency, a relative technological contraction and technical inefficiency. Nevertheless, since 2010, there have been slight improvements in the productivity components of the housing sector in Cameroon from year to year. The sector recorded remarkable gains in technical efficiency (75\%; $5.2 \%$ and 80\%) in 2016, 2017 and 2018, respectively. As for technological efficiency, we observe that the sector has a lot of difficulties in absorbing innovative technologies. The sector recorded a gain in efficiency between 2017 and $2018(2.7 \%$ and $12.1 \%)$. A gain in efficiency of scale is equally observed between 2017 and 2018 (2.5\% and 60\%). These results conform to those obtained by Snyman and Smallwood (2017), in the South African housing industry. However, studies carried out in developed countries reveal contrary results with relatively high levels of productivity (Chen et al., 2011). These results provide very important information to guide efforts to improve the productivity of the housing sector in Cameroon. The results show that the decline in the productivity of the housing sector in Cameroon is linked to poor management of available resources and a lack of technological innovation. In addition, the size of the companies remains too small to achieve good performance.

\section{Conclusion and Implications}

The demographic growth of African states in general, and of Cameroon in particular, confers a role of social stability, equity and justice to the housing sector. In addition, the perspectives of economic opportunities of this sector reaffirm its strategic role in the development of developing countries. These different issues challenge the productivity of the housing sector. As Solow (1956) affirms, an increase in productivity is a source of economic growth and improvement in well-being. Unfortunately, less scientific attention has 
been paid to the productivity of the housing sector in SSA countries. This study evaluates the productivity of the housing sector in Cameroon. Furthermore, the study shows that the housing sector in Cameroon has low productivity.

These results suggest two implications. First, a fall in technical efficiency implies poor management of resources within the housing sector. Technical efficiency translates the technical capacity of the housing sector to increase its output with a given level of input, or inversely; the capacity to reduce its inputs for a given level of production. Second, a decline in technological efficiency reflects a weak level of innovation or modernisation in the housing sector in Cameroon. An increase in the productivity of the housing sector in Cameroon would require, on one hand a better allocation of resources, and on the other hand, the reinforcement of the innovation capacity and the modernisation of production and organisational techniques. The decline in the recorded productivity can be interpreted as the result of: a misallocation of resources; weak technical progress and lack of organisational. To increase total factor productivity in the sector firms need to develop new production systems, such as the use of production technology adapted to local materials which would help to reduce production costs and increase production volume.

\section{References}

Allen, S.G. (1985). Why Construction Industry Productivity is Declining. Review of Economi Statistic, 117(4), pp.661-665.

Alinaitwe, M.H., Mwakali, J.A. \& Hansson, B. (2007). Factor Affecting the Productivity of Bulding Craftsmen-studies of Uganda. Journal of Civil Engineering and Management, 13(3), pp.169-176.

Barro, R.J. (1990). Government Spending in a Simple Model of Endogeneous Growth. Journal of Political Economy, 98(5), pp.103-125.

Borcherding, J.D. (1976). Improving Productivity in Industrial Construction. Journal of The Construction division, 102(4), pp.599-614.

Carlaw, K.I. \& Lipsey, R.G. (2001). Externalities Versus Technological Complementarities: A Model of GPT-driven, Sustained Growth. In A Paper Presented at The Conference in Honour of the 20th Anniversary of Nelson and Winter's Book An Evolutionary Theory Of Economic Change, Aalborg Denmark, pp.12-15.

Cassimatis, P.J. (1969). Economics of The Construction Industry. New York: National Industrial Conference Board.

Centre for Affordable Housing Finance in Africa (2018). A Review of Some of Africa's Housing Finance Markets- 2018. Centre for Affordable Housing in Africa.

Chau, K.W. (1993). Estimating Industry-level Productivity Trends in The Building Industry From Building Cost and Price Data. Construction Management and Economics, 11(5), pp.370-383.

Chen, S., Jefferson, G.H. \& Zhang, J. (2011). Structural Change, Productivity, Growth and Industrial Transformation in China. China Economic Review, 22(1), pp.133-150. 
Coelli, T.J., Rao, D.P., O’Donnell, C.J. \& Battese, G.E. (1998). An Introduction to Productivity and Efficiency Analysis. New York: Springer Science.

Corrado, C., Haskel, J. \& Jona-Lasinio, C. (2017). Knowledge Spillovers, ICT and Productivity Growth. Oxford Bulletin of Economics and Statistics, 79(4), pp.592-618.

Dacy, D.C. (1965). Productivity and Price Trends in Construction Since 1947. The Review of Economics and Statistics, pp.406-411.

Diewert, Erwin (2002). Harmonized Indexes of Consumer Prices: Their conceptual Foundations. ECB Working Paper, No. 130, European Central Bank (ECB).

Duranton, G. (2008). From Cities to Productivity and Growth in Developing Countries. Canadian Journal of Economics/Revue Canadienne d'Economique, 41(3), pp.689-736.

Dyckhoff, H. \& Spengler, T.S. (2010). Produktionswirtschaft: Eine Einführung. Springer-Verlag.

Englander, A.S. \& Gurney, A. (1994). Medium-term Determinants of OECD Productivity. OECD Economic Studies, 22 (Spring), pp.49-109.

Fare, R., Färe, R., Fèare, R., Grosskopf, S. \& Lovell, C.K. (1994). Production frontiers. Cambridge: Cambridge University Press.

Farrell, M.J. (1957). The Measurement of Productive Efficiency. Journal of the Royal Statistical Society: Series A (General), 120(3), pp.253-281.

Gullickson, W. \& Harper, M.J. (1999). Possible Peasurement Bias in Aggregate Productivity Growth. Monthly Lab. Rev, 122, pp.47.

Hacker, R.S. (2003). The Effect of Residential Crowding on Labour Productivity With Evidence From The Twilight of Polish Socialism', Real Estate Economics, 27, pp.135-167.

Hsieh, C.T. \& Moretti, E. (2019). Housing Constraints and Spatial Misallocation. American Economic Journal: Macroeconomics, 11(2), pp.1-39.

Jessua, C. (1991). Histoire de la Lhéorie Economique. FeniXX.

Kazaz, A., Manisali, E. \& Ulubeyli, S. (2008). Effect of Basic Motivational Factors on Construction Workforce Productivity in Turkey. Journal of Civil Engineering and Management, 14(2), pp.95-106.

Koch, J.A. \& Moavenzadeh, F. (1979). Productivity and Technology in Construction. Journal of the Construction Division, 105(4), pp.351366.

Koehn, E., \& Caplan, S.B. (1987). Work Improvement Data for Small and Medium Size Contractors. Journal of Construction Engineering and Management, 113(2), pp.327-339.

Koopmans, T.C. (1951). An Analysis of Production as an Efficient Combination of Activities. In Koopmans T.C. (Eds) Activity Analysis of Production and Allocation, New York: John Wiley and Sons Inc. pp.33-97.

Krugman, P. (2014). Four Observations on Secular Stagnation. Secular Stagnation: Facts, Causes and Cures, pp.61-68.

Law, J. (1987). Technology and Heterogeneous Engineering: The Case of Portuguese Expansion. The Social Construction of Technological Systems: New Directions in The Sociology and History of Technology, 1, pp.1-134. 
Leibenstein, H. (1966). Allocative Efficiency vs. "X-efficiency". The American Economic Review, 56(3), pp.392-415.

Lucas Jr, R.E. (1988). On The Mechanics of Economic Development. Journal of Monetary Economics, 22(1), pp.3-42.

Maclennan, D. \& Miao, J. (2015). Housing: a Modern Definition. I. Hardman 'Octavia: A Life More Noble'. London: Octavia Press.

Malmquist, S. (1953). Index Numbers and Indifference Surfaces. Trabajos de Estadistica y de Investigacion Operativa, 4(2), pp.209-242.

Maloney, W.F. (1983). Productivity Improvement: The Influence of Labour. Journal of Construction Engineering and Management, 109(3), pp.321-334.

Mason, G. \& Osborne, M. (2007). Productivity, Capital-intensity and Labour Quality at Sector Level in New Zealand and the UK (No. 07/01). New Zealand Treasury.

Ministry of Housing and Urban Development in Cameroon (2018). Annual Report on Housing in Cameroon. MINHUD. Available at: http://www.minhdu.gov.cm. pp.14-46.

National Institute of Statistics (2010). Annual Report on The General Census of Enterprises in Cameroon. Available at: http://www.statisticscameroon.org/fr5/index.php. pp.1-40.

National Institute of Statistics (2018a). Cameroon National Report for Housing, URL: http://cameroon.opendataforafrica.org.

National Institute of Statistics (2018b). Report of the Third Cameroon Household Survey. Available at: http://www.ilo.org/microdata/index.php. pp.1-185.

Nelson, C.R. \& Winter, S. (1982). Organizational capabilities and behavior: An Evolutionary Theory of Economic Change.

Oloke, O.C., Oni, A.S., Babalola, D.O. \& Ojelabi, R.A. (2017). Incentive Package, Employee's Productivity and Performance of Real Estate Firms in Nigeria. European Scientific Journal, 13(11), pp.246-260.

Orr, A. (1989). Productivity Trends in New Zealand: A Sectoral \& Cyclical Analysis 1961-1987 (Vol. 48). New Zealand Institute of Economic Research.

Penrose, E. (1959). The Theory of The Growth of The Firm. New York: John Wiley \& Sons.

Pieper, P.E. (1991). The Measurement of Construction Prices: Retrospect and Prospect. In Fifty Years of Economic Measurement: The Jubilee of The Conference on Research in Income and Wealth. Chicago: University of Chicago Press, pp. 239-272.

Piketty, T., Saez, E. \& Stantcheva, S. (2014). Optimal Taxation of Top Labour Incomes: A Tale of Three Elasticities. American Economic Journal: Economic Policy, 6(1), pp.230-71.

Quesnay, F. (1766). Problème Economique. Oeuvres Economiques Complètes et Autres Textes. Paris: Institut National d'Études Démographiques, pp.597-618.

Ricardo, D. (1821). On The Principles of Political Economy. J. Murray.

Romer, P.M. (1986). Increasing Returns and Long-run Growth. Journal of Political Economy, 94(5), pp.1002-1037. 
Schriver, W.R. \& Bowlby, R.L. (1985). Changes in Productivity and Composition of Output in Building Construction, 1972-1982. The Review of Economics and Statistics, pp.318-322.

Shephard, R.W. (1953). Cost and Production Functions. Princeton: Princeton University Press.

Smith, A. \& Stewart, D. (1963). An Inquiry into the Nature and Causes of the Wealth of Nations (Vol. 1). Homewood, Ill: Irwin.

Snyman, T. \& Smallwood, J. (2017). Improving productivity in The Business of Construction. Procedia Engineering, 182, pp.651-657.

Solow, R.M. (1956). A Contribution to The Theory of Economic Growth. The Quarterly Journal of Economics, 70(1), pp.65-94.

Stokes, H.K. (1981). An Examination of The Productivity Decline in The Construction Industry. The Review of Economics and Statistics, pp.495-502.

Tan, W. (2000). Total Factor Productivity in Singapore Construction. Engineering, Construction and Architectural Management, 7(2), pp.154-158.

World Bank (2017). Global Economic Prospects. Washington D.C: The World Bank Group 